\title{
KEBERSYUKURAN, KESEPIAN, DAN DISTRES PSIKOLOGIS PADA MAHASISWA DI MASA PANDEMI COVID-19
}

\author{
Aryo Bima Fahtoni ${ }^{1}$ dan Ratih Arruum Listiyandini ${ }^{2}$ \\ ${ }^{1}$ Fakultas Psikologi, UIN Sunan Gunung Djati \\ Jalan A.H. Nasution No.105, Bandung, Jawa Barat \\ ${ }^{2}$ Fakultas Psikologi, Universitas YARSI \\ Jalan Letjend Suprapto, Cempaka Putih Jakarta Pusat \\ E-mail: fathoniaryo@gmail.com
}

\begin{abstract}
ABSTRAK
Penelitian ini bertujuan untuk melihat hubungan antara kebersyukuran, kesepian, dan kondisi kesehatan mental pada mahasiswa di masa pandemi. Penelitian ini menggunakan metode kuantitatif dengan dengan teknik analisis uji korelasi. Teknik sampling yang digunakan dalam penelitian ini adalah convenience sampling. Instrumen yang digunakan adalah adaptasi DASS-21 untuk mengukur distres psikologis, skala kebersyukuran untuk mengukur rasa syukur, dan adaptasi skala UCLA-3 Loneliness Scale untuk mengukur kesepian. Hasil analisis menunjukkan bahwa kebersyukuran berkorelasi negatif dan signifikan dengan distres psikologis (depresi, kecemasan, dan stres) maupun kesepian pada mahasiswa. Hal ini mengindikasikan bahwa semakin tinggi kebersyukuran yang dimiliki oleh mahasiswa, maka semakin rendah gejala depresi, stres, kecemasan, dan kesepian yang dialami. Hasil penelitian ini diharapkan dapat sebagai acuan untuk tenaga pendidik untuk memberikan sosialisasi, pendampingan, dan penurunan beban perkuliahan kepada responden sehingga diharapkan mampu menjaga stabilitas emosi mahasiswa mampu terkendali.
\end{abstract}

Kata kunci; kebersyukuran; depresi; kecemasan; stres; kesepian

\section{GRATITUDE, LONELINESS, AND PSYCHOLOGICAL DISTRESS IN UNDERGRADUATE STUDENTS DURING COVID-19 PANDEMIC}

\begin{abstract}
This study aims to examine the relationship between gratitude, loneliness, and mental health conditions in college students during the pandemic. This study uses quantitative methods with correlation test analysis techniques. The sampling technique used in this study was convenience sampling. The instruments used were the adaptation of the DASS-21 to measure psychological stress, the gratitude scale to measure gratitude, and the adaptation of the UCLA-3 Loneliness Scale to measure loneliness. The results of the analysis show that gratitude has a negative and significant correlation with psychological distress (depression, anxiety, and stress) and loneliness in students. This indicates that the higher the gratitude of the students, the lower the symptoms of depression, stress, anxiety, and loneliness they experience. The results of this study are expected to serve as a reference for teaching staff to provide socialization, assistance, and reduce the burden of lecturing towards respondents so that they are expected to be able to keep the emotional stability of students under control.
\end{abstract}

Keyword; gratitude; depression; anxiety; stress; loneliness 


\section{PENDAHULUAN}

Sejak pengumuman resmi pertama pada 31 Desember 2019 oleh Komisi Kesehatan Kota Wuhan (WHO, 2020), COVID 19 dengan cepat menyebar di Cina hingga menyebar ke negara lain di antara akhir 2019 dan awal 2020. Kasus COVID 19 di Indonesia dikonfirmasi untuk pertama kalinya pada tanggal 2 Maret 2020. Hingga pada 29 Maret 2020, kasus ini meningkat menjadi 1.285 kasus di 30 provinsi. Lima provinsi yang paling banyak terjangkit COVID-19 adalah Jakarta (675), Jawa Barat (149), Banten (106), Jawa Timur (90), dan Jawa Tengah (63) (Tosepu dkk., 2020). Pandemi ini tidak hanya menambah risiko kematian akibat infeksi virus tetapi juga memberi tekanan psikologis pada orang-orang di seluruh dunia (Duan \& Zhu, 2020).

Sampai sekarang, pasien pengidap COVID-19 terus meningkat. Upaya global yang dilakukan saat ini untuk memperlambat penyebaran dari virus COVID-19 adalah dengan memberikan himbauan agar masyarakat melakukan social distancing atau karantina diri yang dirancang untuk mengurangi interaksi antar individu (Stier, Berman, \& Bettencourt, 2020). Efektivitas program ini bergantung pada kepatuhan individu dan bagaimana masyarakat menjaga kebersihan (Oosterhoff \& Palmer, 2020). Namun, social distancing sendiri dapat memberi dampak buruk pada beberapa aspek kehidupan masyarakat, salah satunya dampak psikologis (Pakpour \& Griffiths, 2020). Berbagai reaksi psikologis muncul di kalangan masyarakat, diantaranya kecemasan, ketakutan, panik, marah, dan depresi (Yang \& Xu, 2020). Di sisi lain, sudah banyak penelitian yang menyebutkan bagaimana kondisi psikologis mempengaruhi imunitas tubuh. Perasaan negatif seperti cemas, takut, dan depresi dapat menurunkan imunitas tubuh seseorang (Kim \& Su, 2020), yang sebetulnya menjadi faktor penting dalam melindungi tubuh dan mengeliminasi virus (Shi dkk., 2020).

Selain himbauan untuk melakukan social distancing, pemerintah di dunia, termasuk Indonesia memerintahkan untuk menutup tempat-tempat umum yang dapat mengundang keramaian, seperti bandara, tempat wisata, dan mall (Yanti dkk., 2020). Dalam bidang pendidikan, banyak negara yang memberikan himbauan agar tidak melaksanakan kegiatan pembelajaran di sekolah atau perguruan tinggi untuk sementara waktu. UN Educational, Scientific, and Cultural Organization memperkirakan bahwa sebanyak 107 negara telah memberikan perintah penutupan sekolah terkait adanya pandemi COVID-19 (Viner dkk., 2020). Akhirnya, sekolah dan perguruan tinggi menerapkan pembelajaran jarak jauh melalui media online (Dingel \& Neiman, 2020), dan proses adaptasi model pembelajaran ini juga dapat menjadi masalah baru bagi kehidupan siswa (Hodges, Moore, Lockee, Trust, \& Bond, 2020).

Universitas memiliki peran penting dalam mendukung mahasiswa dan mengakomodasi kebutuhan akan kesehatan, pendidikan, dan keselamatan mereka. Selama masa pandemi, tindakan yang dilakukan oleh universitas secara signifikan mempengaruhi kesehatan mental dan kesejahteraan siswa (Zhai \& Du, 2020). Sebagai contoh, ditemukan bahwa perubahan situasi dan metode belajar dapat menyebabkan stres akut di antara beberapa siswa karena kurangnya waktu untuk penyesuaian (Meng, dkk., 2020).

Distres psikologis didefinisikan sebagai kondisi negatif yang mencakup didalamnya perasaan depresi dan kecemasan. Depresi adalah perasaan sedih yang mendalam yang menyebabkan perasaan menyalahkan diri sendiri (Mirowsky \& Ross, 2003). Berdasarkan penelitian sebelumnya, sekitar 24,9\% mahasiswa di Cina mengalami kecemasan akibat dari wabah COVID-19. Di Indonesia sendiri berdasarkan analisis data penelitian yang dilakukan pada 139 orang pelajar, sebanyak 54\% mengalami kecemasan dengan kategori tinggi (Fitria \& Ifdil, 2020). Hal ini dapat diakibatkan oleh stresor ekonomi dan keterlambatan akademik yang secara positif berkaitan dengan tingkat gejala kecemasan mahasiswa Cina selama masa pandemik (Cao dkk., 2020). Ditambah lagi adanya himbauan social distancing atau karantina diri, ternyata berasosiasi dengan kondisi psikososial negatif seperti gejala depresi, kemarahan, stres, PTSD, kesepian, kecemasan dan stigmatisasi (Health dkk., 2020). Kondisi ini juga membuat interaksi sosial di masyarakat modern seakan menjadi terbatas sehingga dapat mempengaruhi kepada rasa kesepian pada masyarakat (Banerjee \& Ray, 2020).

Salah satu cara untuk menurunkan perasaan negatif seperti depresi, kecemasan, dan rasa kesepian adalah dengan bersyukur. Bersyukur didefinisikan sebagai kebahagiaan hati atas nikmat yang diterima dan diikuti dengan mengarahkan semua anggota tubuh secara untuk taat pada Tuhan atas segala nikmat yang telah diberikanNya (Adang, Azti, \& Irfan, 2015). Bersyukur merujuk pada kondisi kognitif-afektif yang berkaitan dengan pemberian persepsi positif bahwa seseorang menerima suatu keuntungan dari sebuah peristiwa. Persepsi positif itulah yang digunakan untuk mengurangi distrespsikologis (Mason, 2019). Penelitian sebelumnya menunjukkan bahwa bersyukur dan pemaknaan dalam hidup menjadi faktor yang dapat 
mengurangi depresi dan dapat meningkatkan kehidupan positif pada individu (Disabato, Kashdan, Short, \& Jarden, 2016). Disebutkan juga bahwa bersyukur menjadi faktor penting untuk melindungi diri dari psikopatologi dan dapat memprediksi emosi negatif seperti depresi dan kecemasan (Petrocchi \& Couyoumdjian, 2016).

Mengingat adanya dampak pandemi COVID-19 pada segala aspek kehidupan, salah satunya kesehatan mental mahasiswa, serta potensi kebersyukuran sebagai pendukung kondisi psikologi positif, peneliti tertarik untuk mengetahui tingkat distrespsikologis dan rasa kesepian yang dialami oleh mahasiswa selama pandemi dan mengeksplorasi hubungan antara kebersyukuran, kesepian dan distrespsikologis pada mahasiswa di masa pandemi ini.

\section{METODE}

Penelitian ini menggunakan pendekatan kuantitatif, yaitu suatu pendekatan yang menjelaskan fenomena menggunakan data numerik yang dianalisis menggunakan metode berbasis matematika (Yilmaz, 2013). Penelitian dilakukan dengan desain cross-sectional, dimana pengambilan data seluruh variabel hanya dilakukan satu kali. Kriteria dari partisipan di dalam penelitian ini adalah mahasiswa S1 yang berkuliah di Jabodetabek dan Bandung. Adapun teknik sampling yang digunakan dalam penelitian ini adalah convenience sampling atau sampling insidental, yang mana sampel diambil berdasarkan ketersediaan dan aksesibilitas peneliti terhadap subjek penelitian. Pengambilan data dilakukan secara online pada tanggal 14 - 16 Mei 2020, dua bulan setelah kasus COVID ditemukan di Indonesia. Analisis uji statistik yang digunakan adalah analisis korelasi spearman dengan bantuan IBM SPSS Statistics 25.

Alat ukur yang digunakan dalam penelitian untuk mengukur kondisi psikologis klinis terkait depresi, kecemasan, dan stres adalah DASS-21 sebanyak 21 item dengan 4 alternatif pilihan (0-3) yang sudah melalui proses adaptasi (Kinanthi, dkk., 2020). DASS-21 memiliki 3 subskala: depresi, kecemasan, dan stres dengan koefisien cronbach $\alpha$ : 0,912 serta memiliki daya pembeda diatas $0,3(0,303-0,758)$.

Untuk mengukur rasa syukur, digunakan versi singkat dari alat ukur rasa syukur versi Indonesia (Listiyandini, Syahniar, \& Paramadina, 2015) dengan jumlah 12 item dengan 6 alternatif jawaban (sangat tidak setuju - sangat setuju). Berdasarkan uji psikometrik, alat ukur ini memiliki reliabilitas 0,874 dan memiliki daya pembeda diatas 0,3 (0,303-0,758). Kebersyukuran memiliki 3 aspek: rasa apresiasi (sense of appreciation), perasaan positif terhadap kehidupan, dan kecenderungan untuk bertindak sebagai ekspresi dari apresiasi dan perasaan positif.

Untuk mengukur kesepian, alat ukur yang digunakan adalah UCLA-3 Loneliness Scale yang sudah diadaptasi (Fauziyyah \& Ampuni, 2018). Alat ukur tersebut memiliki 18 item dengan 4 jawaban alternatif (tidak pernah - sering) serta memiliki reliabilitas 0,883 dan memiliki daya pembeda diatas $0,3(0,303-0,758)$.

\section{HASIL DAN PEMBAHASAN}

Tabel 1. Tabel Demografi Data Partisipan

\begin{tabular}{|c|c|c|c|c|c|}
\hline \multicolumn{3}{|c|}{ Jenis Kelamin } & \multicolumn{3}{|c|}{ Umur } \\
\hline Karakteristik & Jumlah & Persentasi & Karakteristik & Jumlah & Persentasi \\
\hline Laki-laki & 65 & 20,5 & $17-19$ & 143 & 34,2 \\
\hline Perempuan & 241 & 79,5 & $20-22$ & 159 & 52,5 \\
\hline \multicolumn{3}{|c|}{ Lokasi Perguruan Tinggi } & $23-25$ & 4 & 1,32 \\
\hline Karakteristik & Jumlah & Persentasi & \multicolumn{3}{|c|}{ Lama Karantina } \\
\hline Bandung & 236 & 76,9 & Karakteristik & Jumlah & Persentasi \\
\hline
\end{tabular}




\begin{tabular}{ccc|ccc}
\cline { 3 - 5 } Bekasi & 12 & 3,69 & $1-4$ hari & 8 & 2,64 \\
Bogor & 5 & 1,65 & $1-2$ minggu & 13 & 4,29 \\
Depok & 9 & 2,97 & 3 minggu -1 bulan & 16 & 5,28 \\
Jakarta & 27 & 8,91 & $>1$ bulan & 114 & 37,62 \\
Tanggerang & 17 & 5,61 & 2 bulan & 155 & 50,17 \\
\hline
\end{tabular}

Dari proses pengambilan data, didapatkan jumlah responden yang ikut serta dalam penelitian ini sebanyak 306 mahasiswa S1 yang berkuliah di kota Bandung, Jakarta, Bogor, Depok, Tangerang, dan Bekasi. Partisipan menjawab kuesioner yang berisi informasi demografi (usia, jenis kelamin, lokasi perguruan tinggi, dan merantau atau tidak), lalu informasi berapa lama sudah melakukan karantina diri, dan kapan terakhir kali berkumpul dengan banyak orang. Tabel 1 menggambarkan gambaran demografi partisipan penelitian.

Tabel 2: Distribusi frekuensi data DASS-21

\begin{tabular}{|c|c|c|c|}
\hline Gejala & Kategori & Jumlah & Persentasi \\
\hline \multirow{3}{*}{ Depresi } & Normal & 245 & $80.1 \%$ \\
\cline { 2 - 4 } & Ringan & 35 & $11.4 \%$ \\
\cline { 2 - 4 } & Sedang & 25 & $8.2 \%$ \\
& Berat & 1 & $0.3 \%$ \\
\hline \multirow{5}{*}{ Kecemasan } & Normal & 242 & $79.1 \%$ \\
& Ringan & 23 & $7.5 \%$ \\
& Sedang & 33 & $10.8 \%$ \\
& Parah & 7 & $2.3 \%$ \\
& Berat & 1 & $0.3 \%$ \\
\hline \multirow{3}{*}{ Stres } & Normal & 242 & $79.1 \%$ \\
\cline { 2 - 4 } & Ringan & 23 & $7.5 \%$ \\
\cline { 2 - 4 } & Sedang & 36 & $11.8 \%$ \\
\cline { 2 - 4 } & Berat & 5 & $1.6 \%$ \\
\hline
\end{tabular}

Tabel 2 menunjukan bahwa meskipun sebagian besar partisipan dalam kategori normal, terdapat sebanyak 19,9\% yang mengalami gejala depresi ringan sampai berat, 20,6\% yang mengalami gejala kecemasan ringan hingga berat, dan sebanyak $21,1 \%$ mengalami gejala stres ringan hingga berat.

Tabel 3: Skor gejala depresi, kecemasan, stres, rasa syukur, dan kesepian

\begin{tabular}{|l||c|c|c|c|c|}
\hline & Depresi & Cemas & Stres & Syukur & Kesepian \\
\hline Mean & 9.78 & 10.92 & 15.48 & 60.05 & 42.13 \\
\hline N & 306 & 306 & 306 & 306 & 306 \\
\hline Std. Deviation & 8.000 & 9.419 & 9.146 & 7.597 & 9.670 \\
\hline
\end{tabular}

Dalam penelitian ini, sebelumnya dilakukan uji normalitas, yaitu uji yang digunakan untuk menilai apakah data terdistribusi normal atau tidak (Jarque \& Bera, 1987). Hasil Uji normalitas menggunakan program SPSS menggunakan uji Kolmogorov-Smirnov.

Tabel 4: Uji Normalitas 


\begin{tabular}{|c|c|c|c|c|c|c|}
\hline & & $\begin{array}{l}\text { Bersyu } \\
\text { kur }\end{array}$ & $\begin{array}{l}\text { Kese } \\
\text { pian }\end{array}$ & Depresi & $\begin{array}{c}\text { Kecema } \\
\text { san }\end{array}$ & Stress \\
\hline $\mathrm{N}$ & & 306 & 306 & 306 & 306 & 306 \\
\hline \multirow[t]{2}{*}{$\begin{array}{l}\text { Normal } \\
\text { Parameters }{ }^{\mathrm{a}, \mathrm{b}}\end{array}$} & $\begin{array}{l}\text { Mea } \\
\mathrm{n}\end{array}$ & 60.05 & $\begin{array}{l}42.1 \\
3\end{array}$ & 4.89 & 5.46 & 7.74 \\
\hline & $\begin{array}{l}\text { Std. } \\
\text { Devi } \\
\text { ation }\end{array}$ & 7.597 & $\begin{array}{l}9.67 \\
0\end{array}$ & 4.000 & 4.709 & 4.573 \\
\hline \multirow{4}{*}{$\begin{array}{ll}\text { Most } & \text { Extreme } \\
\text { Difference } & \end{array}$} & Abso & .106 & .062 & .120 & .153 & .102 \\
\hline & lute & .060 & .062 & .120 & .153 & .102 \\
\hline & $\begin{array}{l}\text { Posit } \\
\text { ive }\end{array}$ & -.106 & $\begin{array}{r}-.04 \\
4\end{array}$ & -.111 & -.123 & -.062 \\
\hline & $\begin{array}{l}\text { Nega } \\
\text { tive }\end{array}$ & & & & & \\
\hline Test Statisic & & .106 & .062 & .120 & .153 & .102 \\
\hline $\begin{array}{l}\text { Asymp. Sig. } \quad \text { (2- } \\
\text { Tailed) }\end{array}$ & & $.000^{\mathrm{c}}$ & $\begin{array}{r}.000 \\
\mathrm{c}\end{array}$ & $.000^{\mathrm{c}}$ & $.000^{\mathrm{c}}$ & $.000^{\mathrm{c}}$ \\
\hline
\end{tabular}

$* \operatorname{sig} \mathrm{p}<0.05$ (1-tailed)

Berdasarkan hasil pengujian dengan taraf signifikansi 0,05, dimana Asymp, signifikansi yang diperoleh dari hasil pengolahan lebih besar dari nilai taraf signifikansinya, yaitu 0,042, maka data untuk mengukur variabel penelitian menunjukan hasil yang signifikan atau menerima $\mathrm{H} 1$, artinya bahwa data sampel tidak berdistribusi normal. Maka dalam analisis data akan digunakan uji korelasi spearman.

Tabel 5: Uji korelasi spearman

\begin{tabular}{|l|c|c|c|c|c|}
\hline \multicolumn{1}{|c|}{ Variabel } & 1 & 2 & 3 & 4 & 5 \\
\hline 1. Depresi & - & $.634^{* *}$ & $.782^{* *}$ & $-.363^{* *}$ & $.431^{* *}$ \\
\hline 2. Cemas & & - & $.726^{* *}$ & $-.497^{* *}$ & $.508^{* *}$ \\
\hline 3. Stres & & & - & $-.341^{* *}$ & $.410^{* *}$ \\
\hline 4. Syukur & & & & $-.479^{* *}$ \\
\hline 5. Kesepian & & & & & - \\
\hline
\end{tabular}

$* * \mathrm{p}<0,01$

Tabel 5 menunjukkan bahwa depresi, kecemasan, stres, dan kesepian berkorelasi positif satu sama linnya. Hal ini mengindikasikan bahwa gejala distres psikologis juga seringkali berhubungan dengan perasaan kesepian. Ditemukan bahwa kesepian memiliki hubungan yang positif dan signifikan dengan depresi $(\mathrm{r}=0.431$, $\mathrm{p}<0,01)$, kecemasan $(\mathrm{r}=0,508, \mathrm{p}<0,01)$, dan stres $(\mathrm{r}=0,410, \mathrm{p}<0,01)$. Sebaliknya, ditemukan bahwa bersyukur berkorelasi negatif dan signifikan dengan depresi $(r=-0,363, p<0,01)$, cemas $(r=-0,497, p<0,01)$, 
stres $(\mathrm{r}=-0,341, \mathrm{p}<0,01)$, dan kesepian $(\mathrm{r}=-0,479, \mathrm{p}<0,01)$. Hal ini menunjukkan bahwa apabila mahasiswa memiliki rasa syukur yang tinggi, akan diikuti juga dengan rendahnya gejala depresi, cemas, stres, dan kesepian yang dialaminya.

Studi ini menunjukkan bahwa sangat penting memperhatikan kondisi kesehatan mental mahasiswa di masa pandemi, khususnya mengenai kecemasan, depresi, stress, dan kesepian yang dialami. Terlebih lagi, kondisi psikologis negatif seperti depresi, kecemasan, stres, dan kesepian saling berkorelasi positif satu sama lainnya dengan nilai korelasi di atas 0,6. Berdasarkan penelitian Bao (2020) disebutkan bahwa sekitar 24,9\% mahasiswa mengalami kecemasan pada saat periode wabah COVID-19. Pada penelitian yang kami lakukan, ditemukan bahwa mahasiswa yang mengalami gejala kecemasan ringan hingga berat mencapai 20,6\%.

Di dalam sebuah studi disebutkan bahwa saat masa pandemi, pencarian loneliness dalam Google Trends meningkat (Brodeur, Clark, Flèche, \& Powdthavee, 2020). Rasa kesepian secara signifikan dapat memperparah serta mempengaruhi depresi (Erzen \& Çikrikci, 2018), stres (Hackett, Poole, Hunt, Panagi, \& Steptoe, 2019), dan kecemasan (Narchal, 2017). Hal ini dibuktikan dalam penelitian kami yang menunjukkan bahwa kesepian berkorelasi positif dengan dengan kondisi distres psikologis lainnya.

Pada kesepian, bersyukur memiliki peran dalam mengurangi rasa kesepian, hal ini dikarenakan bersyukur memang berasosiasi dengan perasaan bahagia dan kepuasan hidup (Caputo, 2015). Rasa syukur juga berkorelasi secara negatif dengan rasa kesepian, dalam sebuah studi menyebutkan bahwa seseorang dengan rasa beryukur yang tinggi memiliki kesempatan kecil untuk merasa kesepian, peran fungsional rasa syukur dapat memperkuat hubungan sosial (Connell, Shea, \& Gallagher, 2016). Intervensi bersyukur berupa latihan menulis rasa syukur akan kehidupan juga dapat menurunkan kesepian (Bartlett \& Arpin, 2019).

Pada distrestekanan psikologis, depresi dan kecemasan merupakan bagian dari distres psikologis yang sangat berkaitan, tetapi faktor-faktor yang berkontribusi pada tingkat depresi dan kecemasan, seperti emosi juga berbeda-beda (Jinghui, Yuxin, \& Dong, 2020). Di dalam penelitian ini ditunjukkan bahwa bahwa kebersyukuran berkorelasi negatif dengan kondisi distres psikologis, yaitu depresi, kecemasan, stres. Meskipun terdapat adanya mahasiswa yang memiliki peningkatan gejala depresi, stres, kecemasan, ditemukan bahwa rasa syukur dapat berkorelasi secara negatif dengan distres psikologis yang dialami. Penemuan ini konsisten dengan riset yang menyatakan bahwa secara eksperimental, kebersyukuran menurunkan gejala depresi melalui atribusi positif, yang dapat melindungi orang dari stres dan depresi (Lin, 2015). Selain itu, intervensi berupa rasa syukur secara signifikan dapat menurunkan gejala kecemasan dan depresi (Cregg \& Cheavens, 2020).

Kecemasan bisa terjadi karena adanya perubahan sistem pembelajaran menjadi pembelajaran jarak jauh atau media online (Bao, 2020). Selain itu, kecemasan siswa mungkin disebabkan oleh semakin melebarnya jarak antara orang-orang akibat karantina dan dapat semakin memburuk akibat tidak adanya komunikasi interpersonal (Xiao, 2020). Sementara itu, terkait dengan depresi dan stres, di dalam penelitian ini ditemukan bahwa sebanyak 19,9\% mahasiswa mengalami gejala depresi ringan sampai berat dan sebanyak $21,1 \%$ mahasiswa mengalami gejala stres ringan hingga berat. Beberapa faktor yang menyebabkan mahasiswa merasa tertekan dapat diakibatkan dari biaya asrama yang hangus, hingga pembatalan acara pertukaran dan upacara kelulusan yang sudah direncanakan sebelumnya (Lee, 2020).

Terdapat beberapa faktor yang mungkin menyebabkan munculnya depresi, stres, kecemasan, dan kesepian pada mahasiswa. Sebagai contoh, penelitian di Cina menemukan bahwa orang yang tinggal di daerah perkotaan, tinggal bersama orang tua, dan memiliki pendapatan yang stabil adalah faktor yang membuat mahasiswa dalam keadaan stabil selama wabah COVID-19 (Cao dkk., 2020). Di sisi lain, dalam sebuah studi mahasiswa yang memiliki gejala sugestif terhadap COVID-19 ditemukan bahwa kesehatan yang buruk berasosiasi dengan stres, kecemasan, dan depresi. Sebaliknya, ketersediaan informasi mengenai pencegahan khusus, seperti mencuci tangan, dapat mengurangi efek ini (Wang dkk., 2020).

Adanya perintah untuk tinggal di rumah atau karantina diri juga berkaitan dengan kecemasan yang lebih besar, kekhawatiran akan keuangan, dan kesepian (Dzousa, Quadros, Juzer, \& Mamun, 2020). Hanya saja, hal ini belum digali lebih lanjut di dalam penelitian ini sehingga perlu adanya penelitian lebih lanjut untuk mengetahui relevan atau tidaknya kondisi ini di Indonesia.

Adapun keterbatasan pada penelitian ini adalah pengambilan data yang dilakukan secara online dan dilakukan di masa lockdown akibat pandemi, juga subjek yang secara demografi masih terlalu luas. Pada penelitian berikutnya, peneliti menyarankan untuk menindaklanjuti penelitian dengan mencari variabel yang 
menjadi pengaruh atau faktor pada variabel lainnya, dan meneliti lebih dalam bagaimana demografi seperti kondisi ekonomi dan asal daerah mempengaruhi variabel-variabel penelitian.

\section{SIMPULAN}

Penelitian menemukan bahwa di masa pandemi, mahasiswa mengalami gejala distres psikologis pada tingkat yang perlu untuk diperhatikan. Selain itu, ditemukan juga bahwa variabel distres psikologis juga saling berkorelasi secara positif dan signifikan, mengindikasikan bahwa semakin tinggi salah satu gejala distres psikologis, dapat berpotensi memicu gejala distres psikologi yang lainnya. Namun demikian, kebersyukuran berkorelasi negatif dan signifikan dengan distres psikologis (depresi, kecemasan, dan stres) dan kesepian pada mahasiswa. Semakin tinggi kebersyukuran yang dimiliki oleh mahasiswa, maka semakin rendah gejala depresi, stres, kecemasan, dan kesepian yang dialaminya. Oleh karena itu, kebersyukuran menjadi faktor yang potensial untuk dipertimbangkan sebagai pelindung dari kondisi kesehatan mental mahasiswa di masa pandemi ini. Hasil penelitian ini diharapkan dapat sebagai acuan untuk tenaga pendidik untuk memberikan sosialisasi, pendampingan, dan penurunan beban perkuliahan kepada responden sehingga diharapkan mampu menjaga stabilitas emosi mahasiswa mampu terkendali.

\section{DAFTAR PUSTAKA}

Adang, H., Azti, M., \& Irfan, F. (2015). Faktor-faktor yang berperan dalam Kebersyukuran (Gratitude) pada orangtua anak berkebutuahn khusus perspektif Psikologi Islam. Psympathic Jurnal Ilmiah Psikologi, 2(105), 94-101.

Bao, W. (2020). COVID-19 and online teaching in higher education: A case study of Peking University. Human Behavior and Emerging Technologies, 2(2), 113-115. https://doi.org/10.1002/hbe2.191

Bartlett, M. Y., \& Arpin, S. N. (2019). Gratitude and loneliness: Enhancing health and well-being in older adults. Research on aging, 41(8), 772-793. https://doi.org/10.1177/0164027519845354

Brodeur, A., Clark, A. E., Fleche, S., \& Powdthavee, N. (2020). Assessing the impact of the coronavirus lockdown on unhappiness, loneliness, and boredom using Google Trends. arXiv preprint arXiv:2004.12129.

https://doi.org/10.20473/jaki.v8i2.2020.4-14

Cao, W., Fang, Z., Hou, G., Han, M., Xu, X., \& Dong, J. (2020). The psychological impact of the COVID-19 epidemic on college students in China. Psychiatry Research, $287(\mathrm{March}), 112934$. https://doi.org/10.1016/j.psychres.2020.112934

Caputo, A. (2015). The relationship between gratitude and loneliness: The potential benefits of gratitude for promoting social bonds. Europe's Journal of Psychology, 11(2), 323.

https://doi.org/10.5964/ejop.v11i2.826

Chang, J., Yuan, Y., \& Wang, D. (2020). Mental health status and its influencing factors among college students during the epidemic of COVID-19. Journal of Southern Medical University, 40(2), 171-176. https://doi.org/10.12122/j.issn.1673-4254.2020.02.06

Connell, B. H. O., Shea, D. O., \& Gallagher, S. (2016). Mediating effects of loneliness on the gratitude-health link. Personality and Individual Differences, 98, 179-183. https://doi.org/10.1016/j.paid.2016.04.042

Cregg, D. R., \& Cheavens, J. S. (2021). Gratitude interventions: Effective self-help? A meta-analysis of the impact on symptoms of depression and anxiety. Journal of Happiness Studies, 22(1), 413-445. https://doi.org/10.1007/s10902-020-00236-6

Dsouza, D. D., Quadros, S., Hyderabadwala, Z. J., \& Mamun, M. A. (2020). Aggregated COVID-19 suicide incidences in India: Fear of COVID-19 infection is the prominent causative factor. Psychiatry Research, 290, e 113145. https://doi.org/10.1016/j.psychres.2020.113145

Dingel, J. I., \& Neiman, B. (2020). How many jobs can be done at home?. Journal of Public Economics, 189, 104235.

Disabato, D. J., Kashdan, T. B., Short, J. L., \& Jarden, A. (2017). What predicts positive life events that influence the course of depression? A longitudinal examination of gratitude and meaning in life. Cognitive 
Therapy and Research, 41(3), 444-458. https://doi.org/10.1007/s10608-016-9785-x

Duan, L., \& Zhu, G. (2020). Psychological interventions for people affected by the COVID-19 epidemic. The Lancet Psychiatry, 7(April), 300-302. https://doi.org/10.1016/S2215-0366(20)30073-0

Erzen, E., \& Çikrikci, Ö. (2018). The effect of loneliness on depression: A meta-analysis. International Journal of Social Psychiatry, 64(5), 427-435. https://doi.org/10.1177/0020764018776349

Fauziyyah, A., \& Ampuni, S. (2018). Depression tendencies, social skills, and loneliness among college students in Yogyakarta. Jurnal Psikologi, 45(2), 98-106. . https://doi.org/10.22146/jpsi.36324

Fitria, L., \& Ifdil, I. (2020). Kecemasan remaja pada masa pandemi Covid -19. Jurnal Education, 6(1), 1-4.

Pakpour, A. H., \& Griffiths, M. D. (2020). The fear of COVID-19 and its role in preventive behaviors. Journal of Concurrent Disorders, 2(1), 58-63.

Hackett, R. A., Poole, L., Hunt, E., Panagi, L., \& Steptoe, A. (2019). Loneliness and biological responses to acute stress in people with Type 2 diabetes. Psychophysiology, 56(6), e13341. https://doi.org/10.1111/psyp.13341 .

Hodges, C., Moore, S., Lockee, B., Trust, T., \& Bond, A. (2020). The difference between emergency remote teaching and online learning. Educause review, 27, 1-12.

Kim, S. W., \& Su, K. P. (2020). Using psychoneuroimmunity against COVID-19. Brain, behavior, and immunity, 87, 4-5. https://doi.org/10.1016/j.bbi.2020.03.025

Kinanthi, M., Listiyandini, R. A., Amaliah, U., \& Ramadhanty, R. (2020). Adaptasi Alat Ukur DASS-21 Versi Indonesia pada Populasi Mahasiswa.

Lee, J. (2020). Mental health effects of school closures during COVID-19. The Lancet Child \& Adolescent Health, 4(6), 421.

Li, Y., Qin, Q., Sun, Q., Sanford, L. D., Vgontzas, A. N., \& Tang, X. (2020). Insomnia and psychological reactions during the COVID-19 outbreak in China. Journal of Clinical Sleep Medicine, 16(8), 1417-1418. Lin, C. (2015). Gratitude and depression in young adults: The mediating role of self-esteem and wellbeing. Personality and Individual Difference $\quad$ s, 87, 30-34. https://doi.org/10.1016/j.paid.2015.07.017

Listiyandini, R. A., Nathania, A., Syahniar, D., Sonia, L., \& Nadya, R. (2015). Mengukur rasa syukur: Pengembangan model awal skala bersyukur versi Indonesia. Jurnal Psikologi Ulayat: Indonesian Journal of Indigenous Psychology, 2(2), 473-496. https://doi.org/10.24854/jpu22015-41

Mason, H. D. (2019). Gratitude, well-being and psychological distress among South African university students. Journal of Psychology in Africa, 29(4) , 354-360. https://doi.org/10.1080/14330237.2019.1647492

Mirowsky, J., \& Ross, C. E. (2003). Social causes of psychological distress. Transaction Publishers.

Narchal, R., \& McDavitt, S. A. (2017). Loneliness and anxiety sensitivity: understanding behavioural avoidance in the lonely. Acta Psychopathologica. https://doi.org/10.4172/2469-6676.100130

Oosterhoff, B., \& Palmer, C. (2020). Psychological Correlates of News Monitoring, Social Distancing, Disinfecting, and Hoarding Behaviors among US Adolescents during the COVID-19 Pandemic. PsyArXiv Preprints.

Petrocchi, N., \& Couyoumdjian, A. (2016). The impact of gratitude on depression and anxiety: The mediating role of criticizing, attacking, and reassuring the self. Self and Identity, 15(2), 191205. https://doi.org/10.1080/15298868.2015.1095794

Röhr, S., Müller, F., Jung, F., Apfelbacher, C., Seidler, A., \& Riedel-Heller, S. (2020). Psychosocial Impact of Quarantine Measures During Serious Coronavirus Outbreaks: A Rapid Review. Psychiat Prax, 179-189

Shi, Y., Wang, Y., Shao, C., Huang, J., Gan, J., \& Huang, X. (2020). COVID-19 infection: the perspectives on immune responses. Cell Death \& Differentiation, 1451-1454. https://doi.org/10.1038/s41418-020-05303

Stier, A. J., Berman, M. G., \& Bettencourt, L. M. A. (2020). COVID-19 attack rate increases with city size. Mansueto Institute for Urban Innovation Research Paper Forthcoming.

Taherdoost, H. (2016). Sampling Methods in Research Methodology; How to Choose a Sampling Technique for. $\operatorname{SSRN}, 5(2), 18-27$.

Tosepu, R., Gunawan, J., Effendy, D. S., Lestari, H., Bahar, H., \& Asfian, P. (2020). Correlation between weather and Covid-19 pandemic in Jakarta, Indonesia. Science of The Total Environment, 725, 138436. https://doi.org/10.1016/j.scitotenv.2020.138436 
Tull, M. T., Edmonds, K. A., Scamaldo, K. M., Richmond, J. R., Rose, J. P., \& Gratz, K. L. (2020). Psychological Outcomes Associated with Stay-at-Home Orders and the Perceived Impact of COVID-19 on Daily Life. Psychiatry Research, 289(May), 113098. https://doi.org/10.1016/j.psychres.2020.113098

Viner, R. M., Russell, S. J., Croker, H., Packer, J., Ward, J., Stansfield, C., Mytton, O., Bonell, C., Booy, R. (2020). School closure and management practices during coronavirus outbreaks including COVID-19: a rapid systematic review. The Lancet Child and Adolescent Health, 4(5), 397-404. https://doi.org/10.1016/S2352-4642(20)30095-X

Wang, C., Pan, R., Wan, X., Tan, Y., Xu, L., Ho, C. S., \& Ho, R. C. (2020). Immediate psychological responses and associated factors during the initial stage of the 2019 coronavirus disease (COVID-19) epidemic among the general population in China. International journal of environmental research and public health, 17(5), 1729.

Xiao, C. (2020). A Novel Approach of Consultation on 2019 Novel Coronavirus (COVID-19) Related Psychological and Mental Problems : Structured Letter Therapy. Psychiatry Investigation, 17(2), 175

World Health Organization. (2020). Covid-19 Situation Report. In World Health Organization (Vol. 31, Issue 2).

Yanti, B., Wahyudi, E., Wahiduddin, W., Novika, R. G. H., Arina, Y. M. D. A., Martani, N. S., \& Nawan, N. (2020). Community knowledge, attitudes, and behavior towards social distancing policy as prevention transmission of COVID-19 in indonesia. Jurnal Administrasi Kesehatan Indonesia, 8(2), 4-14.

Yilmaz, K. (2013). Comparison of quantitative and qualitative research traditions: Epistemological, theoretical, and methodological differences. European journal of education, 48(2), 311-325. Zhai, Y., \& Du, X. (2020). Addressing collegiate mental health amid COVID-19 pandemic. Psychiatry research, 288, 113003. 